Etihad: Journal of Islamic Banking and Finance

Vo. 1, No. 2, Juli-Desember 2021: 82-97

\title{
ANALISIS PERBANDINGAN EFISIENSI PEMBIAYAAN BUS DENGAN BPRS DI JAWA BARAT TAHUN 2017-2019
}

\author{
Jasmin Bunga Islami ${ }^{1 *}$, Trisiladi Supriyanto ${ }^{2}$, Lili Puspita Sari ${ }^{3}$ \\ 1,2,3 Universitas Pembangunan Nasional Veteran Jakarta, Indonesia \\ Email: jasmin.bunga@upnvj.ac.id, trisiladi.supriyanto@gmail.com, \\ lilipuspitasari@upnvj.ac.id
}

\begin{abstract}
The development of Islamic banking in Indonesia is increasingly progressing quite rapidly. This development is evidenced by the increasing total number of Islamic commercial banks, as well as the very large number of Islamic people's financing banks. This study aims to investigate the comparison between BUS and BPRS. This study uses a quantitative methodology with data analysis techniques using Data Envelopment Analysis (DEA), and a different test using an independent sample t-test. The population used is 5 Islamic Commercial Banks (BUS) and 5 Sharia People's Financing Banks (BPRS) in West Java with data samples of fixed assets, savings, operational costs, financing, and operating profit. This study uses secondary data sourced from the official website of the Financial Services Authority. The results of this study are that BPRS has a higher average efficiency level than BUS, and there is no significant difference between BUS efficiency and BPRS in 2017, 2018, and 2019 based on DEA CRS and DEA VRS.
\end{abstract}

Keywords: BPRS, BUS, Efficiency, Financing

\begin{abstract}
Abstrak: Berkembangnya perbankan syariah di Indonesia semakin memiliki kemajuan yang cukup pesat. Perkembangan ini dibuktikan dari angka total bank umum syariah yang meningkat, serta angka bank pembiayaan rakyat syariah yang berjumlah sangat besar. Penelitian ini bertujuan menginvestigasi perbandingan antara BUS dengan BPRS. Penelitian ini memakai metodologi kuantitatif dengan teknik analisis data memakai Data Envelopment Analysis (DEA), serta uji beda menggunakan sampel independent test. Populasi yang digunakan adalah lima Bank Umum Syariah (BUS) dan lima Bank Pembiayaan Rakyat Syariah (BPRS) di Jawa Barat dengan sampel data aset tetap, simpanan, biaya operasional, pembiayaan, dan laba operasional, kemudian data sekunder yang bersumber dari website resmi Otoritas Jasa Keuangan. Hasil dari penelitian menjelaskan bahwa BPRS memiliki rata-rata tingkat efisiensi yang lebih tinggi dibandingkan dengan BUS, serta tidak terdapatnya perbedaan yang signifikan antara efisiensi BUS dengan BPRS pada tahun 2017, 2018, dan 2019 berdasarkan DEA CRS maupun DEA VRS.
\end{abstract}

Keywords: BPRS, BUS Efisiensi Pembiayaan 
Etihad: Journal of Islamic Banking and Finance Vo. 1, No. 2, Juli-Desember 2021: 82-97

\section{PENDAHULUAN}

Di kala dunia ilmu pengetahuan semakin berevolusi, para peneliti kini mengembangkan serta menerapkan ilmunya di berbagai hal tidak terkecuali pada ilmu syariah. Indonesia kini telah berkembang cukup pesat dalam penerapan hukum syariah di berbagai bidang termasuk bidang keuangan dan perbankan. Indonesia menjadi salah satu penggerak atau pembangkit pengembangan industri perbankan syariah di wilayah ASEAN bersama dengan Malaysia. Walaupun perkembangan bank syariah di Indonesia dinilai lebih lambat disamakan dengan Malaysia, namun Indonesia termasuk gencar dalam mengembangkan industri perbankan syariah (Ghozali et al., 2019).

Perkembangan perbankan syariah di Indonesia demikian didukung oleh hadirnya Undang-undang Nomor 10 Tahun 1998 Pasal 1 tentang perbankan yang menjelaskan bahwa bank umum merupakan aktivitas bisnis secara konvensional maupun dengan prinsip syariah yang dapat memberi fasilitas jasa pada laju pembayaran. Sedangkan bank perkreditan rakyat (BPR) ataupun bank pembiayaan rakyat syariah (BPRS) merupakan aktivitas bisnis secara konvensional maupun dengan prinsip syariah namun tidak dapat memberi fasilitas jasa dalam laju pembayaran dalam kegiatannya.

Data OJK menunjukkan jumlah jaringan kantor BUS bertambah satu pada tahun 2018 menjadi empat belas bank serta pada BPRS yang memiliki jaringan kantor sangat besar sehingga mencapai 164 bank (OJK, 2020). Peneliti memiliki ketertarikan untuk melakukan analisis terkait perbandingan efisiensi BUS dengan BPRS. Efisiensi sebuah bank mampu dikatakan tercapai ketika bank terkait dapat melakukan operasi pada skala yang konsisten (constant return to scale). Dalam mencapai efisiensi, terdapat beberapa penyebab yang memiliki pengaruh terhadap keefisienan bank seperti Return on Assets (ROA) dan Capital Adequacy Ratio (CAR) (Ramly \& Hakim, 2017). Selain itu, dengan memerhatikan Biaya Operasional Pendapatan Operasional (BOPO) juga dapat menentukan tingkatan efisiensi suatu bank. Ketika pendapatan operasional lebih kecil dari biaya operasional menunjukkan bahwa bank tersebut mempunyai kinerja yang tidak baik (Fauzi, 2018).

Tabel 1. Perkembangan Kinerja Keuangan BUS dan BPRS (\%)

\begin{tabular}{ccccccc}
\hline & \multicolumn{7}{c}{ Indikator Kinerja } \\
\cline { 2 - 7 } Tahun & \multicolumn{7}{c}{ BUS } & & BPRS \\
\cline { 2 - 7 } & ROA & BOPO & CAR & ROA & BOPO & CAR \\
\hline 2017 & 0,63 & 94,91 & 17,91 & 2,55 & 85,34 & 20,81 \\
2018 & 1,28 & 89,18 & 20,39 & 1,87 & 87,66 & 19,33 \\
2019 & 1,73 & 84,85 & 20,59 & 2,61 & 84,12 & 17,99 \\
& & & & & & \\
\end{tabular}

Sumber : OJK (Data diolah)

Dilihat dari tabel 1, ROA pada BPRS lebih tinggi secara rata-rata dibandingkan dengan ROA pada BUS secara rata-rata pada tahun 2017-2019 yang berarti BPRS dalam menjalankan usahanya memiliki kemampuan manajemen lebih baik dibandingkan dengan BUS. Kemudian 
Etihad: Journal of Islamic Banking and Finance

Vo. 1, No. 2, Juli-Desember 2021: 82-97

berdasarkan data BOPO pada BUS secara umum lebih tinggi dibandingkan dengan BPRS yang berarti BPRS mempunyai tingkat efisiensi lebih baik disamakan dengan BUS. Selanjutnya, tingkat CAR pada BUS dan BPRS mengalami perbedaan. Di mana CAR pada BUS semakin berjalannya tahun mengalami kenaikan, sedangkan CAR pada BPRS semakin berjalannya tahun mengalami penurunan yang berarti BUS semakin baik dalam hal kesanggupan menanggung risiko. Sebaliknya BPRS semakin menurun kemampuannya untuk menanggung risiko.

Walaupun berdasarkan tingkat efisiensi berdasarkan nilai BOPO tergolong cukup efisien, namun dari sisi kecukupan modal untuk menanggung risiko BPRS mengalami penurunan seiring berjalannya waktu. Dikutip dari Liputan6.com (2020), sejak tahun 2005 terdapat setidaknya 102 BPR termasuk di dalamnya BPRS yang ditutup oleh Lembaga Penjamin Simpanan (LPS). Hal ini disebabkan berbagai faktor yang salah satunya adalah kecurangan pada internal bank (Praditya, 2020). Sebelumnya hal yang sama juga terjadi pada tahun 2019 sebagaimana dikutip oleh CNBC Indonesia (2019). LPS menutup enam BPR ataupun BPRS yang disebabkan oleh faktor banyaknya NPL, aktiva produktif berkualitas macet, serta CAR menurun drastis (Sidik, 2019).

Ditutupnya BPRS dapat disebabkan oleh faktor keefisienannya dalam menjalankan usahanya. Maka tingkat efisiensi dinilai penting dalam kegiatan usaha suatu bank. Berdasarkan beberapa fenomena yang terjadi mengenai efisiensi di BUS maupun di BPRS, maka bagaimana tingkat efisiensi pada BUS maupun pada BPRS, serta perbandingan efisiensi antara BUS dengan BPRS dalam persaingan antar perbankan syariah. Selain itu, masih sedikitnya informasi maupun penelitian terkait perbandingan BUS dengan BPRS telah lampunya data yang dipakai pada penelitian yang telah dilaksanakan juga menjadi motivasi peneliti untuk menjalankan penelitian terkait hal ini. Fenomena demikian menimbulkan rumusan masalah dalam penelitian ini yaitu bagaimana tingkat efisiensi pembiayaan pada BUS dan BPRS di Jawa Barat? dan bagaimana perbandingan antara BUS dan BPRS di Jawa Barat?

Data yang dipakai pada penelitian ini ialah data sekunder yang bersumber dari website resmi Otoritas Jasa Keuangan (OJK). Data yang dipakai yaitu data yang di publikasi oleh OJK berupa data laporan keuangan perbankan terkhusus pada BUS dan BPRS pada periode 2017-2019. BUS dan BPRS yang akan dijadikan objek adalah lima BUS terbesar yaitu Bank Muamalat, Bank BNI Syariah, Bank Syariah Mandiri, Bank BRI Syariah, serta Bank BCA Syariah serta lima BPRS terbesar yaitu BPRS Patriot Bekasi, BPRS Harta Insan Karimah Kota Parahyangan, BPRS Baiturridha Pusaka, BPRS Amanah Rabbaniah, dan BPRS Amanah Ummah. Peneliti memilih BPRS di Jawa Barat karena BPRS di Jawa Barat memiliki aset, pembiayaan, serta Dana Pihak Ketiga (DPK) paling besar dibandingkan dengan daerah lain di Indonesia dengan aset sebesar Rp4.676.923, pembiayaan sebesar Rp3.429.187, dan DPK sebesar Rp2.990.399 dalam jutaan rupiah (OJK, 2020).

Penelitian ini memakai metodologi kuantitatif dengan teknik analisis memakai Data Envelopment Analysis (DEA) berguna sebagai pengukur efisiensi BUS dan BPRS serta 
Etihad: Journal of Islamic Banking and Finance

Vo. 1, No. 2, Juli-Desember 2021: 82-97

menggunakan uji beda sampel independen t-test untuk melihat perbandingan efisiensi BUS dengan BPRS. Variabel input yang dipakai untuk pengujian menggunakan DEA yaitu simpanan, aset tetap dan biaya operasional serta dengan output yang dipakai berupa pembiayaan dan laba operasional. Menginvestigasi tingkat efisiensi pembiayaan pada BUS dan BPRS di Jawa Barat serta melakukan analisis perbandingan efisiensi antara BUS dan BPRS di Jawa Barat ialah tujuan dari penelitian ini. Harapan pada penelitian ini adalah dapat memberikan hasil berupa tingkatan efisiensi BUS dan BPRS yang ada di Jawa Barat, serta dapat bermanfaat bagi BUS maupun BPRS bersangkutan sebagai bahan evaluasi atau acuan dalam menjalankan kegiatan usahanya.

\section{TINJAUAN LITERATUR}

\section{Bank Umum Syariah (BUS)}

Pada dasarnya, perbankan syariah berdasarkan jenisnya terdapat tiga jenis, diantaranya adalah Bank Umum Syariah (BUS), Unit Usaha Syariah (UUS), serta Bank Perkreditan Rakyat Syariah (BPRS). Bank Umum Syariah (BUS) ialah bank yang aktivitasnya dijalankan dengan berlandaskan prinsip syariah serta berkegiatan menerima jasa pada lalu lintas pembayaran. Umumnya BUS merupakan bank yang dapat berusaha sebagai Bank Devisa maupun Non-Devisa. BUS memiliki kedudukan yang sama dengan bank umum konvensional. BUS juga memiliki wewenang dalam memberi ketentuan arah kebijakan bank (Kustanti \& Indriani, 2016). Selain BUS, termuat juga Unit Usaha Syariah atau UUS yang merupakan anak perusahaan dari bank konvensional dan menjalankan usahanya berlandaskan prinsip syariah. UUS tidak dapat menjadi UUS selamanya karena ketika UUS telah memiliki aset yang besar dan siap menjadi BUS, maka UUS harus spin-off menjadi BUS.

\section{Bank Pembiayaan Rakyat Syariah (BPRS)}

Bank Pembiayaan Rakyat Syariah (BPRS) ialah bank yang aktivitasnya sama seperti BPR namun harus menerapkan prinsip syariah dalam kegiatannya. Di mana BPRS juga tidak dapat menerima fasilitas jasa lalu lintas pembayaran. BPRS ialah salah satu jenis perbankan syariah yang mempunyai batasan dalam menjalankan kegiatannya yaitu dilarang menjalankan jasa lalu lintas pembayaran (Jelita \& Shofawati, 2019). BPRS memiliki produk yang terbatas, di mana kegiatan yang paling banyak dilakukan ialah pembiayaan dengan hanya memakai beberapa akad. Akad yang umum dipakai ialah akad Mudarabah, Musyarakah dan Murabahah (Janah \& Fanani, 2020). Dalam melaksanakan kegiatannya, BPRS memiliki perbedaan fundamental dengan BUS, di mana BPRS mempunyai larangan mendapat simpanan berupa giro dan tidak dapat berkontribusi pada lalu lintas sistem pembayaran.

\section{Efisiensi}

Efisiensi dapat diartikan sebagai kesanggupan penyelesaian suatu kegiatan dengan baik atau dalam pandangan matematika diartikan dengan upaya melakukan penghitungan rasio output dan input. Efisiensi dapat diartikan tidak hanya melakukan penekanan pada output, namun juga menekan input sebagai usaha guna menggapai target agar tidak terjadi 
Etihad: Journal of Islamic Banking and Finance

Vo. 1, No. 2, Juli-Desember 2021: 82-97

keadaan berlebihan atau boros (Awaluddin et al., 2019). Maka efisiensi dapat diartikan sebagai bentuk hasil atau capaian dari olahan pemasukan sumber daya menjadi keluaran yang tepat seperti yang telah di targetkan. Efisiensi dalam perbankan ialah salah satu indikator penentu kinerja perbankan. Ketika efisiensinya tinggi maka kinerja bank tersebut di indikasi baik serta berlaku sebaliknya. Dalam mengukur tingkat efisiensi tersebut, terdapat pendekatan-pendekatan yang umum dipakai yaitu biaya, profit, dan teknis (L. P. Sari \& Tanjung, 2020).

Pada teknik pengukuran efisiensi, terdapat dua pendekatan yaitu pendekatan berdasarkan rasio keuangan serta pendekatan berdasarkan Operating Research (OR). Pada pendekatan rasio keuangan umumnya dinyatakan dalam kinerja keuangan, seperti return on equity (ROE), return on Asset (ROA), Cost to income ratio (CIR), operating efficiency ratio (OER) Capital Adequacy ratio (CAR). Di sisi lain, pada pendekatan OR, efisiensi dapat diukur memakai beberapa cara yaitu (1) Teknik parametrik, pada teknik ini dapat digunakan Recusive Thick Frontier Approach (RTFA), Distribution-Free Approach (DFA), dan Stochastic Frontier Approach (SFA), dan (2) Teknik non-parametrik, pada teknik ini dapat digunakan Data Envelopment Analysis (DEA), dan Free Disposable Hull (DFH) analisis (Hidayat, 2014). Dalam pengukuran tingkat efisiensi, Hadad et al (2003) berpendapat bahwa ada tiga jenis pendekatan, yaitu pendekatan intermediasi, pendekatan produksi, dan pendekatan aset (Hadad et al., 2003).

Pada penelitian ini metode yang digunakan adalah DEA dengan pendekatan yang dipakai. Merupakan pendekatan intermediasi karena penelitian ini berfokus pada efisiensi pembiayaan, di mana pembiayaan termasuk ke dalam fungsi bank yaitu intermediasi. Selain pada pembiayaan, penelitian ini juga mengukur tingkatan efisiensi profit BUS serta BPRS di Jawa Barat. Produk simpanan, aset tetap, dan biaya operasional digunakan sebagai variabel input serta pembiayaan dan laba operasional dipakai sebagai variabel output dalam penelitian ini.

Pada sisi variabel input, terdapat variabel simpanan yang merupakan jenis produk dalam menghimpun dana dari masyarakat, di mana dalam perbankan syariah diketahui bentuk berbagai produk berwujud giro, tabungan, dan deposito dengan sistem perbankan syariah yang tidak mengenal kehadiran bunga sebagai kontra prestasi terhadap nasabah deposan, namun menggunakan metode bagi hasil serta bonus yang tergantung dari jenis produk yang nasabah pilih (Umam \& Utomo, 2017). Pada BPRS, terdapat sedikit perbedaan pada kegiatan operasionalnya, karena BPRS dilarang mengeluarkan produk giro (Afandi \& Suprayogi, 2019). Selanjutnya pada variabel input terdapat variabel aset tetap yang merupakan jumlah aset yang dimiliki oleh sebuah perusahaan (P. Z. Sari \& Saraswati, 2017). Variabel input terakhir ialah biaya operasional yang merupakan seluruh pengeluaran yang digunakan dengan segera guna mendukung jalannya produktivitas maupun pembelian barang dan jasa yang diperdagangkan dengan penjualan, biaya umum, bunga pinjaman, maupun biaya administrasi (Jumirin \& Lubis, 2018). 
Etihad: Journal of Islamic Banking and Finance

Vo. 1, No. 2, Juli-Desember 2021: 82-97

Selanjutnya, pada sisi output yang pertama ialah pembiayaan yang merupakan kegiatan bank syariah guna melakukan penyaluran dana pada nasabah yang mengalami defisit dana atau berkebutuhan (Rivai, 2017). Pembiayaan menjadi pendapatan utama bank syariah yang ketika dana yang disalurkan semakin besar semakin tinggi pendapatan (Asiyah, 2017). Pembiayaan memiliki garis lurus terhadap profitabilitas karena ketika pembiayaan diberikan tanpa memberikan perhatian terhadap efisiensi maka akan berpengaruh terhadap profitabilitas. Lalu, output kedua ialah laba operasional yaitu sebuah peningkatan keuntungan ekonomi sepanjang periode masa akuntansi bertambahnya aset serta penurunan kewajiban atau utang yang dapat memberi dampak meningkatnya ekuitas yang berasal dari selain ikut serta penanaman modal. Penghasilan hadir dalam bentuk pendapatan maupun keuntungan/laba (Salman, 2017). Maka dapat disimpulkan bahwa laba operasional merupakan selisih antara pendapatan atas kegiatan utama perusahaan dengan beban.

Penelitian mengenai efisiensi sektor perbankan telah dilakukan sebelumnya. Penelitian tentang komparasi antara Bank Syariah dan Bank Konvensional juga dilakukan oleh Ramly \& Hakim (2017). Hasil dalam penelitian menunjukkan nilai efisiensi kedua jenis bank di Indonesia pada masa periode 2012-2014. Pada penelitian tersebut membuahkan hasil berupa penyebab suatu bank efisien yaitu NPF tidak berpengaruh dan FDR, ROA, serta CAR mempunyai pengaruh terhadap efisiensi bank syariah. Berbeda dengan bank konvensional yang seluruh variabelnya memiliki pengaruh terhadap keefisienannya (Ramly \& Hakim, 2017). Penelitian terkait efisiensi sektor perbankan syariah telah dilakukan Banna et al (2019). Sampel yang dipakai pada penelitian ini yaitu 154 sampel bank syariah dari 32 negara selama periode 2011-2017. Hasil penelitian menunjukkan sebagian besar negara kecuali beberapa negara Asia dan Timur Tengah tengah memiliki tren efisiensi yang tidak konsisten di sektor perbankan syariah. Hal ini juga menunjukkan bahwa inklusi keuangan secara signifikan bersekutu dengan efisiensi perbankan syariah (Banna et al., 2019).

\section{METODE PENELITIAN}

Kuantitatif ialah jenis penelitian yang dipakai dalam penelitian ini yaitu dengan metode non-parametrik Data Envelopment Analysis (DEA) serta menggunakan Independent sample t-test guna melakukan perbandingan efisiensi BUS dengan BPRS. Dalam penelitian ini, BUS dan BPRS di Jawa Barat yang berkegiatan selama tahun 2017-2019 menjadi populasi. Teknik sampling purposive dipakai dalam penelitian ini dengan karakteristik sampel dalam penelitian ini ialah bank yang terdaftar di OJK selama periode 2017 hingga 2019 dan memublikasikan laporan keuangan secara lengkap di website OJK, serta 5 BUS terbesar dan 5 BPRS di Jawa Barat terbesar. Data keuangan BUS dan BPRS di Jawa Barat yang termasuk ke dalam karakteristik tertentu pada penelitian ini dijadikan sampel penelitian.

Data sekunder ialah jenis data yang dipakai dalam penelitian ini yang pada penelitin ini didapatkan dari hasil publikasi oleh Otoritas Jasa Keuangan (OJK) atas laporan keuangan BUS dan BPRS selama tahun 2019. Data sekunder yang digunakan berasal dari website resmi 
Etihad: Journal of Islamic Banking and Finance

Vo. 1, No. 2, Juli-Desember 2021: 82-97

milik OJK yang berupa laporan keuangan BUS dan BPRS yang beroperasi selama tahun 2019 yang berupa aset tetap, simpanan, biaya operasional, pembiayaan, dan laba operasional. Adapun teknik pengumpulan data pada penelitian ini memakai dokumentasi.

\section{HASIL DAN PEMBAHASAN}

\section{Uji Data Envelopment Analysis (DEA)}

Data Envelopment Analysis (DEA) digunakan dalam penelitian ini guna menunjukkan tingkat efisiensi BUS dan BPRS secara individu. Data yang digunakan dalam DEA ialah variabel input berupa simpanan, aset tetap, dan biaya operasional serta variabel output berupa laba operasional dan total pembiayaan. Untuk melihat apakah bank terkait efisien dapat dilihat dari nilai Tehnical Efficiency yang berkisar antara 0 hingga 1, di mana bank dapat disimpulkan efisien ketika nilai yang didapatkan ialah 1 yang berarti pula slack bernilai 0 .

Terdapat dua jenis metode dalam pengolahan data DEA yaitu Constant Return to Scale (CRS) dan Variable Return to Scale (VRS). Model CRS merupakan model yang memiliki asumsi, peningkatan input sepadan dengan peningkatan outpu. Asumsi ini dapat diakui ketika unit bisnis yang diuji melakukan produksi dengan optimal (optimum scale). Efisiensi yang ditunjukkan model CRS ini menghasilkan efisiensi overall tehnical. Sedangkan pada model VRS efisiensi yang dihitung ialah efisiensi teknis murni, di mana asumsi ini berlaku walaupun unit bisnis yang di uji. Dalam penelitian ini ialah bank sebagai DMU (Decision Making Unit), tidak beroperasi dalam skala optimal (Tanjung \& Devi, 2018) . Dalam penelitian ini kedua metode tersebut digunakan. Berikut merupakan hasil data yang telah diolah menggunakan metode DEA dengan bantuan aplikasi DEAP 2.1 :

Tabel 2. Hasil pengolahan data BUS dan BPRS menggunakan DEAP 2.1

\begin{tabular}{cccccccc}
\hline \multirow{2}{*}{$\begin{array}{c}\text { Jenis } \\
\text { Bank }\end{array}$} & Bank & \multicolumn{3}{c}{ CRS } & \multicolumn{3}{c}{ VRS } \\
\cline { 3 - 8 } & & $\mathbf{2 0 1 7}$ & $\mathbf{2 0 1 8}$ & $\mathbf{2 0 1 9}$ & $\mathbf{2 0 1 7}$ & $\mathbf{2 0 1 8}$ & $\mathbf{2 0 1 9}$ \\
\hline BUS & BMI & 1.000 & 0.274 & 0.054 & 1.000 & 0.586 & 0.232 \\
BUS & BNIS & 0.425 & 0.687 & 0.115 & 0.519 & 0.726 & 0.144 \\
BUS & BSM & 0.224 & 0.440 & 1.000 & 0.648 & 0.528 & 1.000 \\
BUS & BRIS & 0.470 & 1.000 & 0.245 & 0.651 & 1.000 & 0.451 \\
BUS & BCAS & 1.000 & 0.772 & 0.026 & 1.000 & 1.000 & 0.869 \\
BPRS & BPRS Patriot & 1.000 & 1.000 & 1.000 & 1.000 & 1.000 & 1.000 \\
& Bekasi & & & & & & \\
BPRS & $\begin{array}{c}\text { BPRS HIK } \\
\text { Parahyangan }\end{array}$ & 0.359 & 1.000 & 0.112 & 1.000 & 1.000 & 0.441 \\
BPRS & $\begin{array}{c}\text { BPRS } \\
\text { Baiturridha }\end{array}$ & 1.000 & 1.000 & 1.000 & 1.000 & 1.000 & 1.000
\end{tabular}


Etihad: Journal of Islamic Banking and Finance Vo. 1, No. 2, Juli-Desember 2021: 82-97

\begin{tabular}{cccccccc}
\multicolumn{8}{c}{ Pusaka } \\
BPRS & $\begin{array}{c}\text { BPRS Amanah } \\
\text { Rabbaniah }\end{array}$ & 1.000 & 1.000 & 1.000 & 1.000 & 1.000 & 1.000 \\
BPRS & $\begin{array}{c}\text { BPRS Amanah } \\
\text { Ummah }\end{array}$ & 0.643 & 0.837 & 0.619 & 1.000 & 1.000 & 0.816 \\
& Mean BUS & 0.624 & 0.635 & 0.288 & 0.764 & 0.768 & 0.539 \\
Mean BPRS & 0.800 & 0.967 & 0.746 & 1.000 & 1.000 & 0.851 \\
\hline
\end{tabular}

Sumber : Data diolah (Data Envelopment Analysis)

Mengacu pada hasil pengolahan ada di DEAP 2.1, maka pada tingkat efisiensi pada BUS yang diukur menggunakan DEA dapat disimpulkan bahwa perhitungan efisiensi BUS menggunakan DEA model CRS menunjukkan pada tahun 2017 ada dua BUS yang dapat mencapai nilai efisiensi sempurna yaitu Bank Muamalat Indonesia dan Bank BCA Syariah. Selanjutnya pada tahun 2018 hanya terdapat satu BUS yang mempunyai efisiensi maksimal yaitu Bank BRI Syariah dan pada tahun 2019 juga hanya terdapat satu BUS yang menggapai nilai efisiensi sempurna yaitu Bank Syariah Mandiri. Selanjutnya pada perhitungan efisiensi BUS menggunakan DEA model VRS menunjukkan pada tahun 2017 terdapat dua BUS yang menggapai nilai efisiensi sempurna yaitu Bank Muamalat Indonesia dan Bank BCA Syariah. Kemudian pada tahun 2018 juga terdapat dua BUS yang memiliki efisiensi sempurna yaitu Bank BRI Syariah dan Bank BCA Syariah. Namun pada tahun 2019 hanya terdapat satu BUS yang mencapai nilai sempurna yaitu Bank Syariah Mandiri.

Tingkat efisiensi BPRS diukur dengan menggunakan DEA. Hasil menunjukkan bahwa perhitungan efisiensi BPRS menggunakan DEA model CRS menunjukkan pada tahun 2017 dan 2019, terdapat tiga BPRS yang mencapai nilai efisiensi sempurna yaitu BPRS Patriot Bekasi, BPRS Baiturridha Pusaka, dan BPRS Amanah Rabbaniah. Sedangkan pada tahun 2018 terdapat empat BPRS memiliki tingkat efisiensi sempurna yaitu BPRS Patriot Bekasi, BPRS HIK Parahyangan, BPRS Baiturridha Pusaka, dan BPRS Amanah Rabbaniah. Selanjutnya pada perhitungan efisiensi BPRS menggunakan DEA model VRS menunjukkan bahwa pada tahun 2017 dan 2018 kelima BPRS yang diuji seluruhnya memiliki tingkat efisiensi sempurna. Terakhir, pada tahun 2019 terdapat tiga dari lima BPRS yang diuji mempunyai tingkat efisiensi sempurna yaitu BPRS Patriot Bekasi, BPRS Baiturridha Pusaka, dan BPRS Amanah Rabbaniah.

Berdasarkan tabel 2, maka terdapat $14 \mathrm{DMU}$ dari $30 \mathrm{DMU}(46,6 \%)$ yang memiliki efisiensi secara overall (CRS). Lalu berdasarkan teknis (VRS), terdapat 18 DMU (60\%) yang memiliki tingkat efisiensi sempurna. Sedangkan untuk yang lainnya, terdapat lima DMU yang memiliki tingkat efisiensi di atas 60\% serta 11 DMU di bawah 60\% secara CRS. Lalu pada sisi VRS, terdapat lima DMU yang memiliki tingkat efisiensi di atas $60 \%$ serta 7 DMU di bawah 60\%. Distribusi efisiensi setiap DMU dilihat pada tabel 13 berikut :

Tabel 3. Distribusi Efisiensi 
Etihad: Journal of Islamic Banking and Finance Vo. 1, No. 2, Juli-Desember 2021: 82-97

\begin{tabular}{lrrrrr}
\hline Asumsi & \multirow{2}{*}{$\mathbf{1 0 0 \%}$} & $\begin{array}{r}\mathbf{8 0 \% -} \\
\mathbf{9 9 , 9 \%}\end{array}$ & $\begin{array}{c}\mathbf{6 0 \% -} \\
\mathbf{7 9 , 9 \%}\end{array}$ & $\begin{array}{c}\mathbf{4 0 \% -} \\
\mathbf{5 9 , 9 \%}\end{array}$ & $\begin{array}{c}\mathbf{0 \% -} \\
\mathbf{3 9 , 9 \%}\end{array}$ \\
\hline CRS & 14 & 1 & 4 & 3 & 8 \\
VRS & 18 & 2 & 3 & 5 & 2 \\
\hline \multicolumn{4}{l}{ Sumber }
\end{tabular}

Sumber : Data diolah (Data Envelopment Analysis)

Pengolahan data memakai aplikasi DEAP 2.1 membuahkan hasil perbandingan efisiensi BUS dengan BPRS sebeagai berikut:

Gambar 1. Perbandingan Efisiensi DEA-CRS

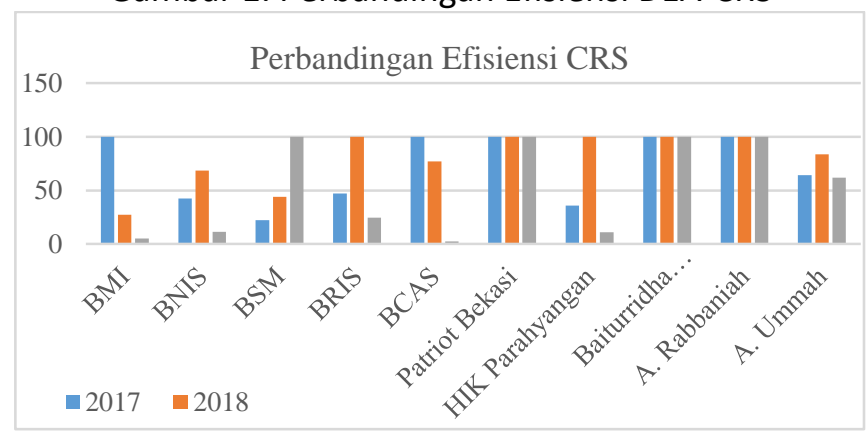

Sumber : Data diolah (Data Envelopment Analysis)

Gambar 2. Perbandingan Efisiensi DEA-VRS

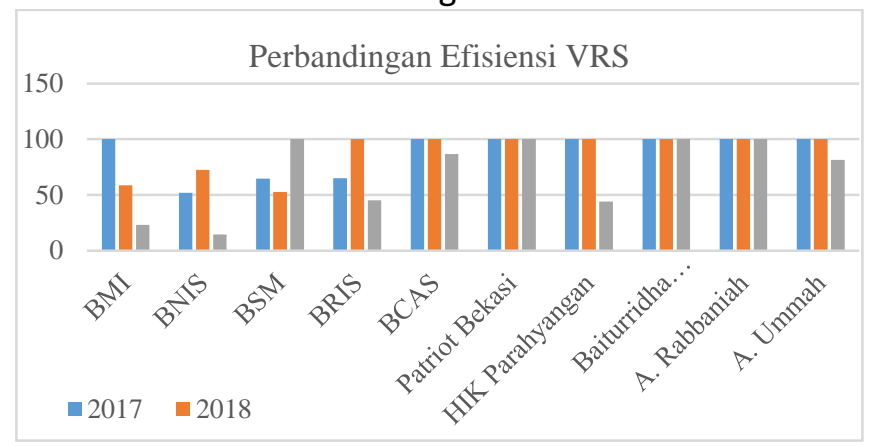

Sumber : Data diolah (Data Envelopment Analysis)

Gambar 1 dan 2 menunjukkan bahwa secara rata-rata BPRS mempunyai nilai efisiensi yang lebih tinggi dibandingkan BUS dengan banyaknya DMU yang mencapai tingkat efisiensi 1 atau $100 \%$. Hal ini sejalan dengan data ROA dan BOPO pada BPRS yang memiliki nilai yang lebih baik dari BUS. Walaupun di sisi lain jumlah CAR pada BPRS semakin menurun yang pada BUS semakin meningkat. Jika dikaitkan dengan jumlah kantor BPRS yang fluktuatif, maka CAR dapat dikatakan sebagai penyebabnya, karena CAR merupakan risiko tertinggi bagi BPRS sebagai lembaga keuangan yang mempunyai modal terbatas dan relatif sulit mendapatkan modal tambahan, sehingga jika angka CAR memburuk maka langsung mempengaruhi kondisi bank secara keseluruhan. Dalam permodalan, BUS dapat mendapatkan penambahan modal anorganik dari BUMN yang menyuntikkan modal ke bank syariah, di mana hal ini dapat menjadi bentuk antisipasi pencadangan bagi bank yang memiliki kualitas pembiayaan 
Etihad: Journal of Islamic Banking and Finance

Vo. 1, No. 2, Juli-Desember 2021: 82-97

rendah. Berdasarkan tingkat ROA dan BOPO serta berdasarkan hasil penelitian ini menghasilkan efisiensi pada BPRS tetap lebih baik. Hal ini disebabkan oleh tidak dimasukkannya variabel permodalan dalam pengujian. Selain itu, laba BPRS yang memiliki kisaran yang lebih tinggi dari BUS juga dapat menjadi pengaruhnya hal ini dikarenakan BPRS mempunyai pasar yang sempit serta memiliki pangsa pasar sendiri.

\section{Uji Independent Sample T-Test}

Independent Sample T Test digunakan sebagai uji beda dalam penelitian ini guna mencari jawaban atas perbandingan atau perbedaan rata-rata efisiensi pada BUS dan BPRS pada tahun 2017 hingga 2019. Untuk membantu pengolahan data, maka digunakan bantuan aplikasi IBM SPSS Statistics 20. Berikut merupakan hasil dari uji beda Independent Sample $T$ Test :

Tabel 4. Hasil Independent Samples Test DEA-CRS Tahun 2017

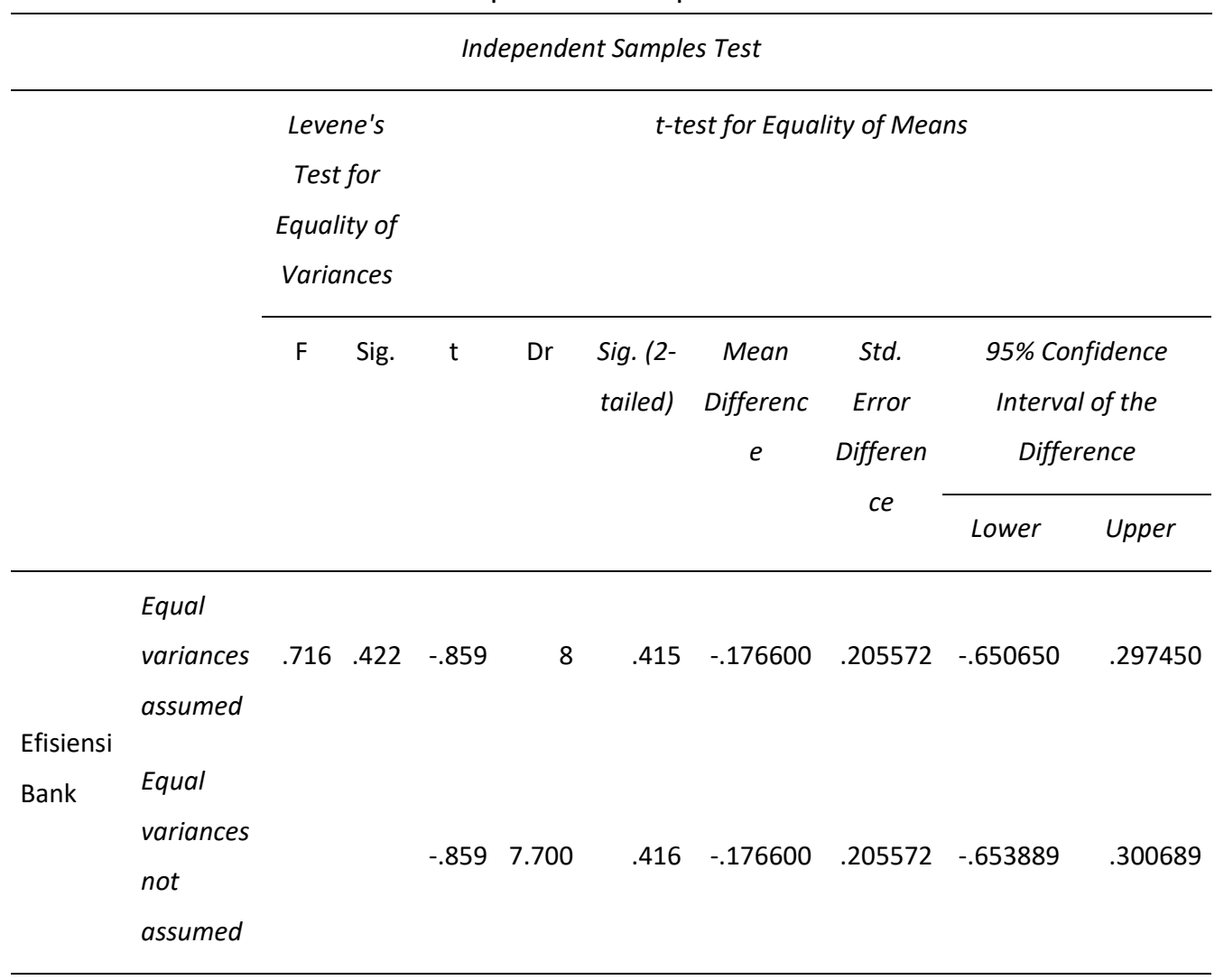

Sumber : data diolah (SPSS)

Tabel 4 merupakan tabel analisis independent sample $t$ test. Tabel 4 menunjukkan bahwa data BUS dan BPRS homogen karena terlihat pada angka Sig. Levene's Test for Equality of Variances menunjukkan angka $0.422>0.05$ (Sujarweni, 2014). Ketika datanya homogen maka tabel "Equal variances assumed" digunakan untuk interpretasi uji beda. Maka dapat ditarik kesimpulan bahwa tidak terdapatnya perbedaan yang signifikan antara nilai efisiensi BUS dan BPRS memakai metode DEA-CRS pada tahun 2017 karena angka signifikansi 2 arah (t-tailed) dalam tabel Equal variances assumed menunjukkan angka 0.415 $>0.05$. 
Etihad: Journal of Islamic Banking and Finance

Vo. 1, No. 2, Juli-Desember 2021: 82-97

Tabel 5. Hasil Independent Samples Test DEA-CRS Tahun 2018

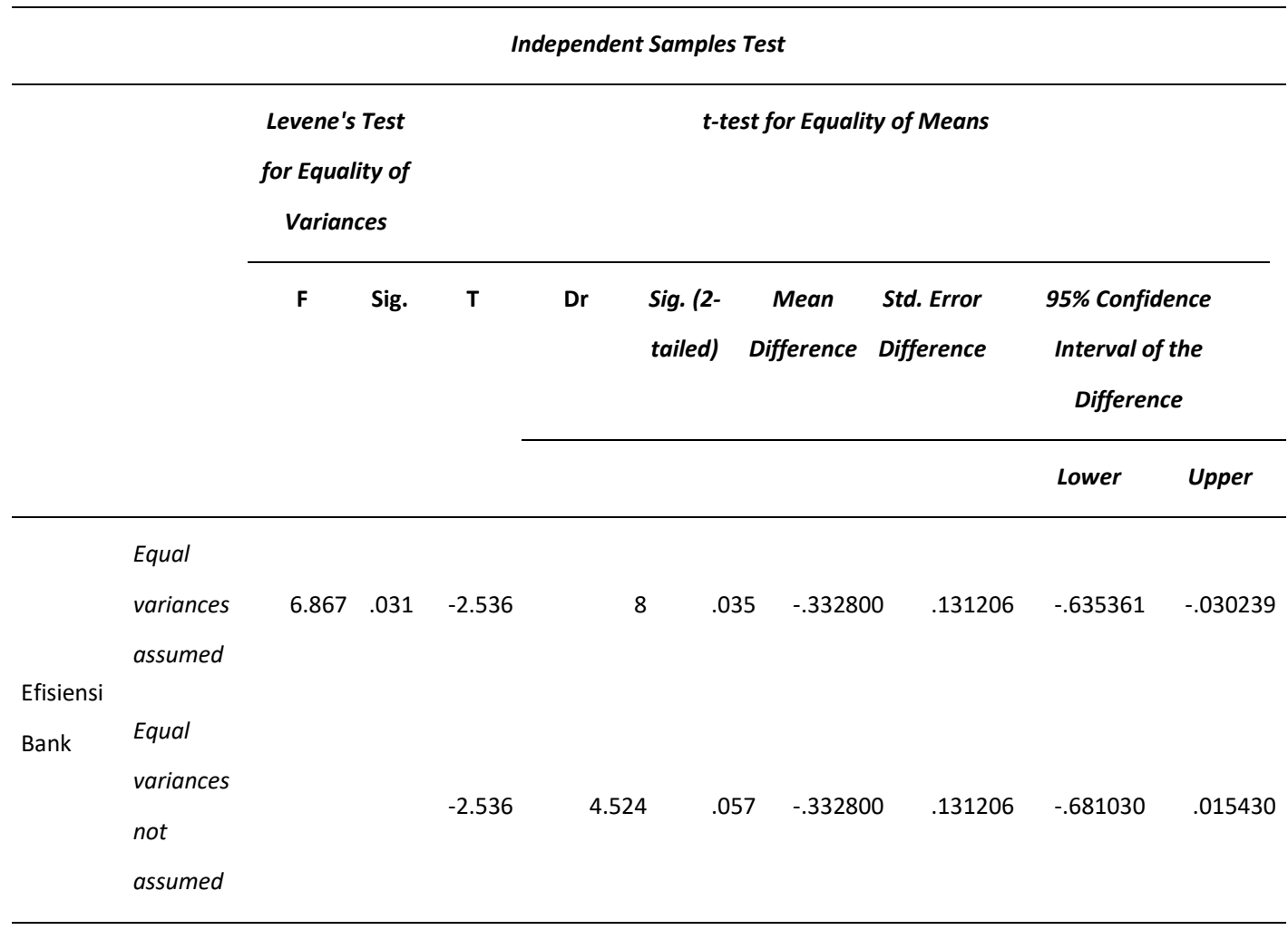

Sumber : data diolah (SPSS)

Tabel 5 memberikan petunjuk bahwa data yang digunakan tidak identik karena nilai Sig. Levene's Test for Equality of Variances senilai $0.031<0.05$. Maka penginterpretasian tabel output Independent Samples T Test di atas mengacu pada angka dalam tabel "Equal variances not assumed". Hasil membuktikan tidak terdapatnya perbedaan yang signifikan antara nilai efisiensi BUS dan BPRS dengan metode DEA-CRS pada tahun 2018 karena angka pada signifikansi 2 arah (t-tailed) dalam tabel Equal variances not assumed menunjukkan angka $0.057>0.05$.

Tabel 6. Hasil Independent Samples Test DEA-CRS Tahun 2019

Independent Samples Test 
Etihad: Journal of Islamic Banking and Finance Vo. 1, No. 2, Juli-Desember 2021: 82-97

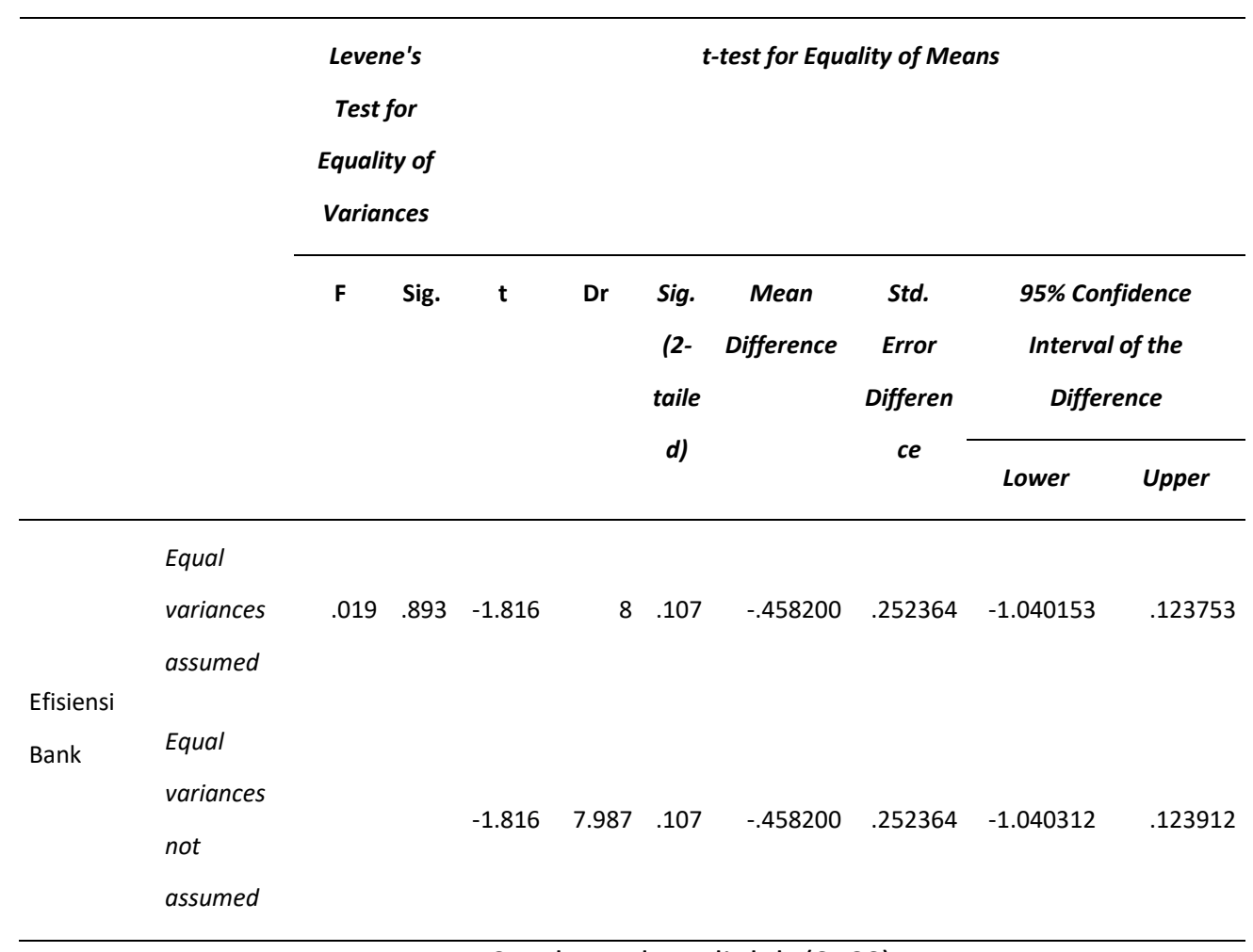

Sumber : data diolah (SPSS)

Terlihat pada tabel 6 bahwa data yang dipakai bersifat homogen dengan dasar bahwa angka pada Sig. Levene's Test for Equality of Variances ialah $0.893>0.05$. Maka uji beda yang akan ditafsirkan ialah signifikansi 2 arah (t-tailed) yang berada pada baris "Equal variances assumed". Hasil yang ditemukan ialah tidak terdapatnya perbedaan yang signifikan antara tingkatan efisiensi BUS dan BPRS memakai metode DEA-CRS pada tahun 2019, kesimpulan ini didasarkan dari angka yang menunjukkan sebesar 0.107 yang memiliki arti lebih besar dari 0.05 .

Tabel 7. Hasil Independent Samples Test DEA-VRS Tahun 2017

Independent Samples Test

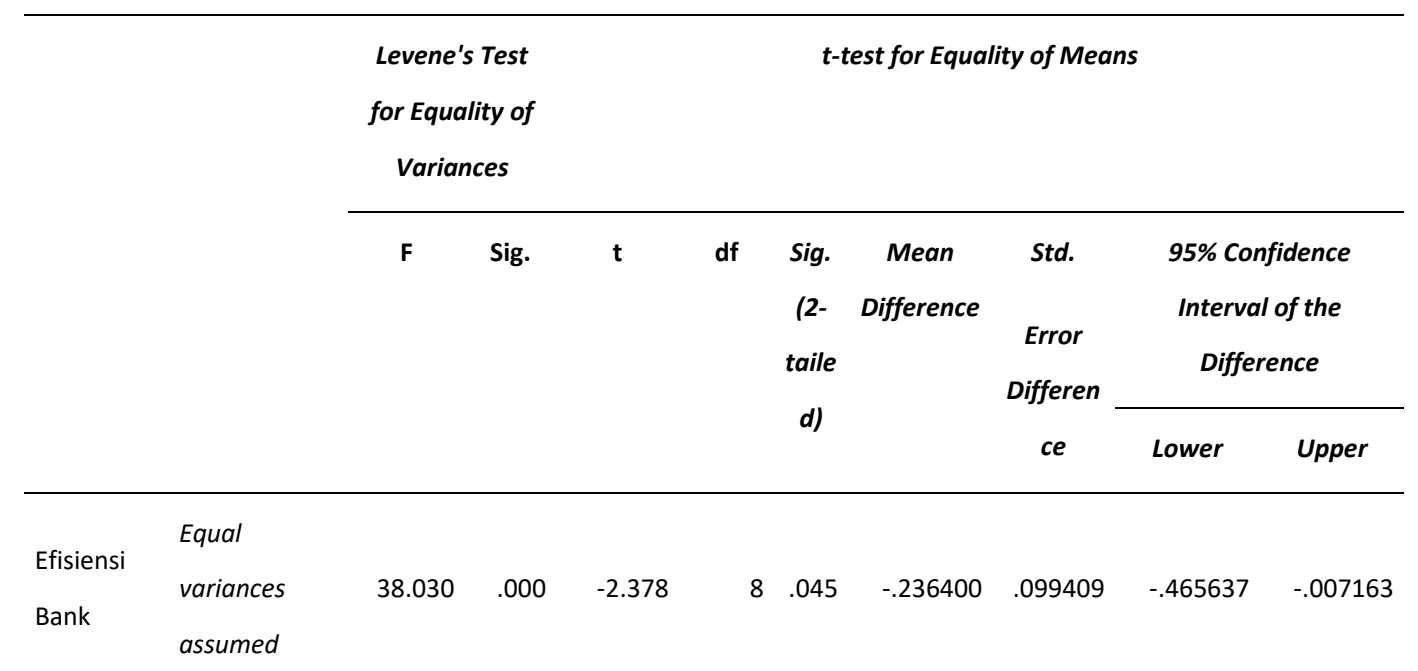


Etihad: Journal of Islamic Banking and Finance Vo. 1, No. 2, Juli-Desember 2021: 82-97

\section{Equal}

variances not

$\begin{array}{lll}-2.378 & 4.000 \quad .076\end{array}$

$-.236400$

.099409

$-.512402$

.039602

assumed

Sumber : data diolah (SPSS)

Hasil dari uji Independent sample t-test tabel 7 ialah tidak identiknya data yang digunakan karena terbukti dari angka pada kolom Sig pada Levene's Test for Equality of Variances ialah $0.000<0.05$. Sehingga interpretasi pengujian uji beda di atas memiliki acuan pada angka yang tertera pada tabel "Equal variances not assumed". Terlihat bahwa nilai signifikansi 2 arah (t-tailed) dalam tabel Equal variances not assumed $0.076>0.05$. Maka hal ini membuahkan hasil bahwa tidak terdapatnya perbedaan yang signifikan antara nilai efisiensi BUS dan BPRS dengan metode DEA-VRS pada tahun 2017.

Tabel 8. Hasil Independent Samples Test DEA-VRS Tahun 2018

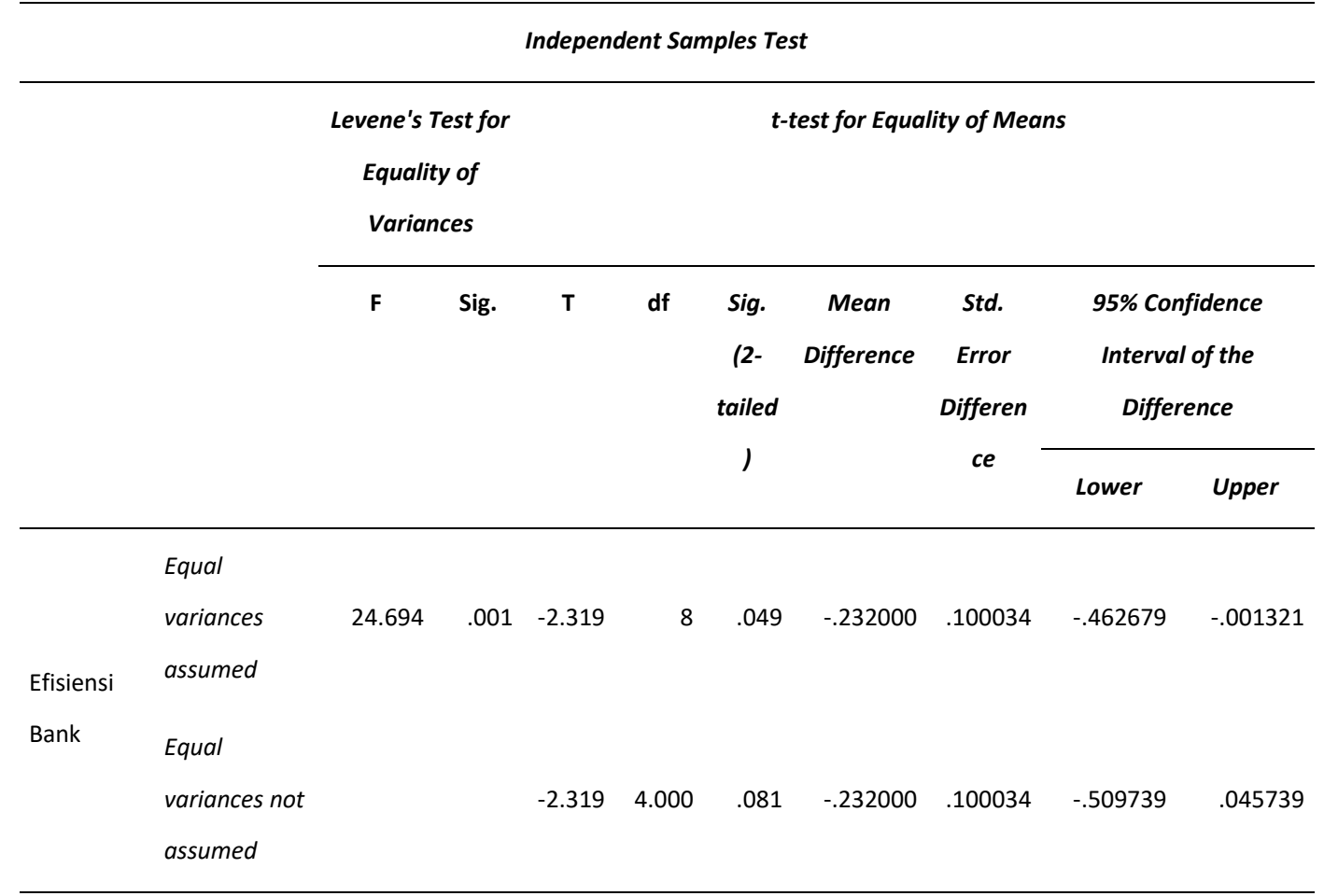

Sumber : data diolah (SPSS)

Pengujian memakai uji beda pada tabel 8 membuahkan hasil tidak identiknya data yang digunakan, hal ini ditunjukkan oleh angka Sig. Levene's Test for Equality of Variances sebesar $0.001<0.05$. Maka sig (2-tailed) yang digunakan untuk diinterpretasi ialah dari baris "Equal variances not assumed". Hasil yang ditunjukkan pada baris Equal variances not assumed ialah tidak terdapatnya perbedaan yang signifikan tingkat efisiensi BUS dan BPRS dengan metode DEA-VRS pada tahun 2018 dengan bukti bahwa pada signifikansi 2 arah (ttailed) menunjukkan angka $0.081>0.05$.

Tabel 9. Hasil Independent Samples Test DEA-VRS Tahun 2019 
Etihad: Journal of Islamic Banking and Finance Vo. 1, No. 2, Juli-Desember 2021: 82-97

\begin{tabular}{|c|c|c|c|c|c|c|c|c|c|c|}
\hline & & \multicolumn{2}{|c|}{$\begin{array}{c}\text { Levene's Test } \\
\text { for Equality of } \\
\text { Variances }\end{array}$} & \multicolumn{7}{|c|}{ t-test for Equality of Means } \\
\hline & & \multirow[t]{2}{*}{$F$} & \multirow[t]{2}{*}{ Sig. } & \multirow[t]{2}{*}{$T$} & \multirow[t]{2}{*}{$\mathrm{Dr}$} & \multirow{2}{*}{$\begin{array}{l}\text { Sig. } \\
(2- \\
\text { tailed } \\
\quad\end{array}$} & \multirow[t]{2}{*}{$\begin{array}{c}\text { Mean } \\
\text { Difference }\end{array}$} & \multirow{2}{*}{$\begin{array}{c}\text { Std. } \\
\text { Error } \\
\text { Differen } \\
\text { ce }\end{array}$} & \multicolumn{2}{|c|}{$\begin{array}{c}\text { 95\% Confidence } \\
\text { Interval of the } \\
\text { Difference }\end{array}$} \\
\hline & & & & & & & & & Lower & Upper \\
\hline Efisiensi & $\begin{array}{l}\text { Equal } \\
\text { variances } \\
\text { assumed }\end{array}$ & 2.433 & .157 & -1.546 & 8 & .161 & -.312200 & .201912 & -.777809 & .153409 \\
\hline Bank & $\begin{array}{l}\text { Equal } \\
\text { variances not } \\
\text { assumed }\end{array}$ & & & -1.546 & 6.794 & .167 & -.312200 & .201912 & -.792594 & .168194 \\
\hline
\end{tabular}

Sumber : data diolah (SPSS)

Pengujian menggunakan Independent sample t-test pada tabel 9 membuahkan hasil berupa data yang digunakan homogen disebabkan karena angka menunjukkan $0.157>0.05$ pada kolom Sig. Levene's Test for Equality of Variances yang artinya data yang digunakan homogen. Angka yang digunakan untuk interpretasi perbedaan terdapat pada baris Equal variances assumed. Dalam baris tersebut memberikan bukti tidak terdapatnya perbedaan yang signifikan antara tingkat efisiensi BUS dengan BPRS di Jawa Barat metode DEA-VRS tahun 2019 karena pada kolom Sig. (2-t-tailed) pada baris equal variances assumed menunjukkan angka $0.161>0.05$.

\section{KESIMPULAN}

Pada pembahasan dan analisis data telah dijelaskan sebuah hasil, serta berpedoman pada masalah dan tujuan penelitian, dengan menggunakan jenis CRS yang menunjukkan bahwa pada tahun 2017 terdapat 2 BUS dan 3 BPRS yang memiliki efisiensi sempurna dengan nilai 1. Sedangkan pada tahun 2018 terdapat 1 BUS dan 4 BPRS yang memiliki tingkat efisiensi sempurna. Kemudian pada tahun 2019 berdasarkan DEA-CRS terdapat 1 BUS dan 3 BPRS yang memiliki efisiensi sempurna. Berbeda dengan hasil DEA-VRS di mana pada tahun 2017 dan 2018 terdapat 2 BUS dan 5 BPRS yang memiliki efisiensi maksimal, di sisi lain pada tahun 2019 mempunyai 1 BUS, dan 3 BPRS yang memiliki efisiensi sempurna.

Selanjutnya, uji beda Independent Sample T Test membuahkan hasil bahwa tidak terdapatnya perbedaan efisiensi yang signifikan antara BUS dan BPRS memakai model DEACRS maupun DEA-VRS selama tahun 2017 hingga 2019. Walaupun berdasarkan uji DEA ditemukannya tingkat efisiensi yang berbeda-beda, namun perbedaan tersebut tidak signifikan. Hal ini dapat disebabkan oleh baik BUS maupun BPRS memiliki kekuatannya masing-masing di mana BUS memiliki modal yang kuat sedangkan BPRS memiliki kekuatan 
Etihad: Journal of Islamic Banking and Finance

Vo. 1, No. 2, Juli-Desember 2021: 82-97

pada laba. Dalam penelitian ini modal tidak digunakan dalam variabel pengujian maka hasil yang muncul ialah BPRS lebih efisien dari BPRS.

Keterbatasan penelitian ini sebagai berikut, data yang digunakan memiliki batasan pada kategori tertentu yaitu data yang diambil hanya data bank yang terdaftar di OJK selama periode 2017-2019, mempublikasikan laporan keuangan selama periode tahun 2017-2019, serta hanya 5 BUS dan 5 BPRS terbesar di Jawa Barat sehingga penilaian tidak menyeluruh. Selain itu, data BPRS yang digunakan merupakan data regional sedangkan data BUS yang digunakan merupakan data BUS secara nasional. Hal disebabkan data yang tersedia di OJK pada BPRS merupakan data BPRS berdasarkan daerah sedangkan untuk BUS merupakan data secara nasional.

Berlandaskan dari hasil pengujian hipotesis serta penjabaran pada pembahasan, maka terdapat saran secara teoritis dan praktis. Secara teoritis disarankan kepada peneliti selanjutnya yang ingin mengkaji topik yang sejenis untuk dapat memperluas periode pengamatan dan memperkaya sampel agar hasil yang didapatkan lebih komprehensif. Sedangkan secara praktis disarankan kepada BUS dan BPRS agar dapat memperhatikan penggunaan input serta output guna penyesuaian terhadap target agar dapat tercapai hasil yang optimal terutama pada BUS dan BPRS yang termasuk ke dalam kategori tidak efisien atau dengan nilai $<1$ atau $<100 \%$. Selanjutnya bagi nasabah disarankan untuk melihat tingkat efisiensi suatu bank sebelum memutuskan untuk berinvestasi pada bank terkait. Penelitian ini diharapkan dapat membantu para nasabah maupun calon nasabah sebagai sumber informasi.

\section{REFERENSI}

Afandi, A. H., \& Suprayogi, N. (2019). Mitigasi Sharia Non-Compliance Risk Pengembangan Produk Keuangan Syariah di Bank Pembiayaan Rakyat Syariah (Studi Kasus : PT. BPRS Mandiri Mitra Sukses). Jurnal Ekonomi Syariah Teori dan Terapan, 5(11), 924. https://doi.org/10.20473/vol5iss201811pp924-940

Asiyah, B. N. (2017). Pengaruh kualitas portofolio pembiayaan terhadap profitabilitas bank mega syariah. An-Nisbah, 03(02).

Awaluddin, M., Mutmainna, A., \& Wardhani, R. S. (2019). Komparasi Efisiensi Penyaluran Kredit pada Bank Umum Syariah (BUS) antara Bank Mega Syariah dan Bank CIMB Niaga Syariah dengan Pendekatan Data Envelopment Analysis (DEA). Al-Mashrafiyah: Jurnal Ekonomi, Keuangan, dan Perbankan Syariah, 3, 95-107.

Banna, H., Ahmad, R., \& Sari, N. M. (2019). Does Financial Inclusion Drive the Islamic Banking Efficiency? A Post-financial Crisis Analysis. https://doi.org/10.1142/S0217590819420050

Fauzi, M. (2018). Efisiensi bank pembiayaan rakyat syariah (BPRS) di provinsi Jawa Tengah. Jurnal Ekonomi \& Keuangan Islam, 4(1), 31-40. https://doi.org/10.20885/JEKI.vol4.iss1.art4

Ghozali, M., Azmi, M. U., \& Nugroho, W. (2019). Perkembangan Bank Syariah Di Asia Tenggara : Sebuah Kajian Historis. Jurnal Ekonomi Syariah, 4(1), 44-55. 
Etihad: Journal of Islamic Banking and Finance

Vo. 1, No. 2, Juli-Desember 2021: 82-97

Hadad, M., Santoso, W., Ilyas, D., \& Mardanugraha, E. (2003). Analisis Efisiensi Industri Perbankan Indonesia: Penggunaan Metode Non-paramterik Data Envelopment Analysis (DEA). Direktorat Penelitian dan Pengaturan Perbankan BI.

Hidayat, R. (2014). Efisiensi Perbankan Syariah Teori dan Praktik. Gramata Publishing.

Janah, I. M., \& Fanani, S. (2020). Analisis Kepatuhan Syariah Pembiayaan Musyarakah Pada Bprs Amanah Sejahtera Gresik. Jurnal Ekonomi Syariah Teori dan Terapan, 7(1), 151. https://doi.org/10.20473/vol7iss20201pp151-161

Jelita, W. R. S., \& Shofawati, A. (2019). Manajemen Risiko Operasional Pada PT Bank Pembiayaan Rakyat Syariah (BPRS) Jabal Nur Tebuireng di Surabaya. Falah: Jurnal Ekonomi Syariah, 4(1), 69. https://doi.org/10.22219/jes.v4i1.8733

Jumirin, \& Lubis, Y. (2018). Pengaruh Biaya Operasional Terhadap Peningkatan Pendapatan Operasional Pada Pt.Pelabuhan Indonesia I (Persero) Cabang Belawan. Jurnal Riset $\begin{array}{llll}\text { Akuntansi dan 162-177. } & \text { Bisnis, }\end{array}$ https://doi.org/https://doi.org/10.30596/jrab.v18i2.3310

Kustanti, H., \& Indriani, A. (2016). Analisis Perbandingan Efisiensi Bank Umum Syariah (BUS ) dan Unit Usaha Syariah ( UUS ) dengan Metode Stochastic Frontier Analysis ( SFA ) Periode 2010-2014. Jurnal Studi Manajemen \& Organisasi, 13. http://ejournal.undip.ac.id/index.php/smo\%0Amampu

OJK. (2020). SPS Desember 2020.

Praditya, I. I. (2020, Agustus 4). LPS tutup 103 Bank Sejak 2005. Liputan6.com. liputan6.com/bisnis/read/4322165/lps-tutup-103-bank-sejak-2005\#

Ramly, A. R., \& Hakim, A. (2017). Pemodelan Efisiensi Bank di Indonesia: Perbandingan antara Bank Syariah dan Bank Konvensional. Esensi: Jurnal Bisnis dan Manajemen, 7(2), 131-148. https://doi.org/10.15408/ess.v7i2.

Rivai, A. (2017). Risiko Pembiayaan Murabahah dan Musyarakah pada Profitabilitas Bank Umum Syariah. AL-URBAN: Jurnal Ekonomi Syariah dan Filantropi Islam, 2(1), 189-197. https://doi.org/10.22236/alurban

Salman, K. R. (2017). Akuntansi Perbankan Syariah Berbasis PSAK Syariah (B. Sarwiji (ed.); 2 ed.). PT Indeks.

Sari, L. P., \& Tanjung, H. (2020). Efisiensi di Bank Syariah : Studi Empiris pada Unit Usaha Syariah Bank Pembangunan Daerah di Indonesia. Jurnal Akuntansi dan Keuangan Islam, 8(April), 5-20. https://doi.org/https://doi.org/10.35836/jakis.v8i1.105 EFISIENSI

Sari, P. Z., \& Saraswati, E. (2017). The Determinant of Banking Efficiency in Indonesia ( DEA Approach ). 1(March), 208-229.

Sidik, S. (2019, Juli 29). Banyak Kredit Macet, LPS Tutup 6 BPR Bermasalah. CNBC Indonesia. cnbcindonesia.com/market/20190729091900-17-88153/banyak-kredit-macet-lpstutup-6-bpr-bermasalah

Sujarweni, W. V. (2014). Metodologi Penelitian: Lengkap, praktis, dan mudah dipahami. Pustaka Baru Press.

Tanjung, H., \& Devi, A. (2018). Metodologi Penelitian Ekonomi Islam (P. Oktavianawati (ed.); 2 ed.). Gramata Publishing (Gramata CV).

Umam, K., \& Utomo, S. B. (2017). Perbankan Syariah: Dasar-dasar dan Dinamika 
Etihad: Journal of Islamic Banking and Finance

Vo. 1, No. 2, Juli-Desember 2021: 82-97

Perkembangannya di Indonesia. PT Raja Grafindo Persada. 